June 2018

\title{
Reaching New Scholarly Heights: School of Information Student Research Journal Hits Milestone with 100,000 Full Text Downloads
}

Sandra Hirsh

sandy.hirsh@sjsu.edu

Follow this and additional works at: https://scholarworks.sjsu.edu/ischoolsrj

Part of the Archival Science Commons, Cataloging and Metadata Commons, Collection Development and Management Commons, Information Literacy Commons, Scholarly Communication Commons, and the Scholarly Publishing Commons

\section{Recommended Citation}

Hirsh, S. (2018). Reaching New Scholarly Heights: School of Information Student Research Journal Hits Milestone with 100,000 Full Text Downloads. School of Information Student Research Journal, 8(1). https://doi.org/10.31979/2575-2499.080103 Retrieved from https://scholarworks.sjsu.edu/ischoolsrj/ vol8/iss $1 / 3$

This article is brought to you by the open access Journals at SJSU ScholarWorks. It has been accepted for inclusion in School of Information Student Research Journal by an authorized administrator of SJSU ScholarWorks. For more information, please contact scholarworks@sjsu.edu. 


\title{
Reaching New Scholarly Heights: School of Information Student Research Journal Hits Milestone with 100,000 Full Text Downloads
}

\author{
About Author \\ Sandra Hirsh is Professor and Director of the San José State University School of Information. She has \\ previously worked in product development and R\&D at HP Labs, Microsoft and Linkedln in the Silicon \\ Valley. She is active professionally and has held numerous leadership roles in ALA, ASIS\&T, IFLA and \\ other professional organizations. She co-founded and co-chairs the global Library 2.0 virtual conference \\ series. She is the author of the foundational textbook Information Services Today: An Introduction \\ published by Rowman \& Littlefield; the second edition was published in 2018. She is the co-PI on a 2017 \\ Institute of Museum and Library Services grant titled "Investigation of Possible Uses of Blockchain \\ Technology by Libraries-Information Centers to Support City-Community Goals."
}




\section{Introduction}

Since 2010, the School of Information Student Research Journal (SRJ), formerly the SLIS Student Research Journal, has opened a pathway for library and information science (LIS) graduate students to contribute to LIS research and intellectual inquiry. The $S R J$ is one of many initiatives at the School of Information at San José State University (SJSU) that demonstrates a commitment to "educating future information professionals to contribute to the well-being of global communities" (Hirsh, et. al., 2015, p. S29). As the only double-blind peer reviewed journal promoting graduate student scholarship in library, archives, and information science in North America (SRJ, 2018, About This Journal), the SRJ is a remarkable and unique open access journal that invites graduate students to submit literature reviews, book reviews, and original research for publication. Full-text articles and issues are freely available for downloading at http://scholarworks.sjsu.edu/slissrj/. In her contributing article Participating in the conversation, Editor-in-Chief Otero-Boisvert (2011) quoted David Lanke's mantra that "the mission of librarians is to improve society through facilitating knowledge creation in their communities" (Lankes, 2011). She goes on to say that knowledge creation is the primary goal of the $S R J$, which is affirmed in each of its articles (Otero-Boisvert, 2011). This article reflects on the achievements of the $S R J$, as it reaches this major 100,000 download milestone, by examining download and publishing characteristics, contributor attributes, and article topic trends.

\section{Background}

The need for more scholarly contributions and original research among practitioners is expressed by many in the library and information science (LIS) field. In their content analysis of 1880 articles from LIS scholarly journals and periodicals, Turcios, Agarwal, and Watkins (2014) identified that only 16 percent of the literature qualifies as research. Hayman (2015) infers that information professionals are not producing enough research, and therefore this should be a focus going forward. Partridge and Given (2016) assert the need for LIS professionals to engage in open conversation for research collaboration, and the need to establish evidence-based research work as part of the LIS profession. Evans, Dresang, Campana, and Feldman (2013) dig deeper, emphasizing that LIS programs offer a shortage of courses and opportunities that enable students to participate in authentic field research. They further argue for improvements in research methods education in LIS programs in order to better support the growth of future research in the LIS professional field.

The $S R J$ addresses this gap in both original scholarship and student engagement by opening up a direct avenue for engaging with original research, writing for publication, and experiencing a professional peer-to-peer review process. Being published and contributing to broader communications in the field is of tremendous value, and the opportunity and experience of engaging with the 
writing and submission process alone prepares these new LIS practitioners for future scholarship and contribution.

In addition to offering MLIS students the opportunity to contribute and be published, "the $S R J$ has also provided a unique forum for MLIS candidates to experience scholarly communication as editors, reviewers, teammates, and managers" (Hockin, 2017, p. 1). Figure 3 shows the organizational chart governing the journal, which includes an Editorial Advisory Board and a faculty advisor. All members of the editorial team are graduate students at the iSchool.

Figure 3: School of Information Student Research Journal Editorial Board Organizational Chart

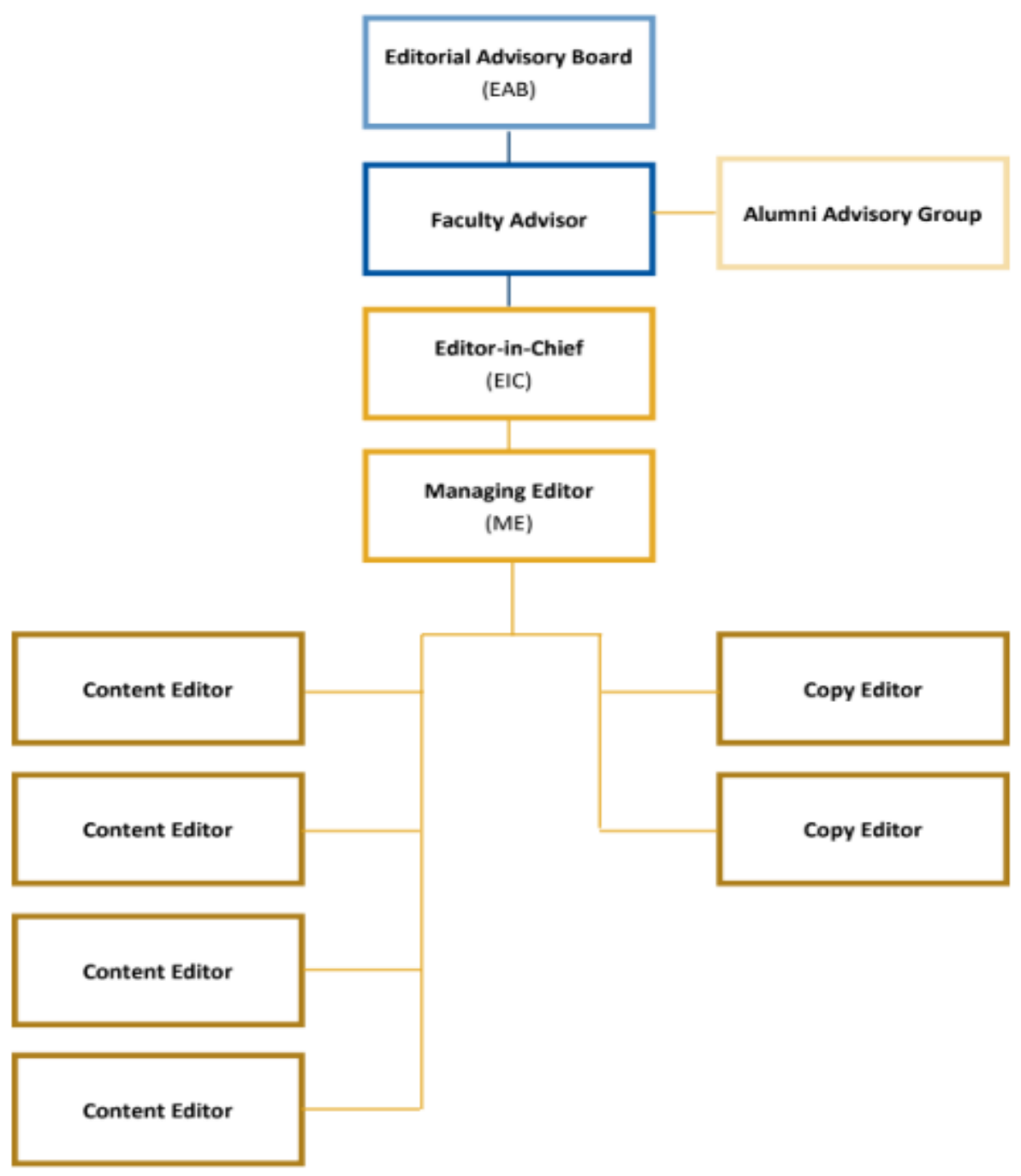

Retrieved from: Student Research Journal. (2018). SRJ Editorial Structure Chart. https://drive.google.com/open?id=0B3MpMolmsWhvQXo1OFRBQUZwZEU

The average editorial team is comprised of an Editor in Chief, a managing editor, six content editors, and two copy editors, each of whom must be a 
currently enrolled graduate student at the iSchool. The team is responsible for developing the journal's aims and scope, managing operations, promoting the journal, and building a strong journal reputation across scholarly LIS platforms (Hockin, 2017, p. 1). They are also responsible for recruiting, promoting, and selecting new editorial team members as vacancies appear. Since its inception, the journal has recruited 64 iSchool graduate students to serve on its editorial team. Forty-five percent of these students served on the editorial team for two issues (or one full volume/year), 23 percent served on only one issue, 22 percent served on three issues, and 5 percent served on four issues. One editor served for five issues, and two students served for six issues (equivalent to three full volumes).

Hockin highlights her experience as Editor-in-Chief (2016-2017) as the most valuable experience from her MLIS experience at the School of Information (Perilli, 2017). She further highlights the many skills that students gain as a result of working on the $S R J$ editorial team, including "critical thinking, project management, leadership and ... research" (Ibid).

The journal is further supported by an Editorial Advisory Board and a faculty advisor. All members of the Editorial Advisory Board are full time faculty with the SJSU School of Information. At the time this article was written, the Editorial Advisory Board includes 25 full time faculty members. The journal's faculty advisor, full-time iSchool faculty member Dr. Anthony Bernier, works closely with the editorial team as a member of the Editorial Advisory Board and was the first contributing faculty member for the journal. His article Reaching escape velocity and the purpose of SLIS Student Research Journal (Bernier, 2011) celebrated the inaugural issue of the journal by providing insight and guidance to student contributors on how to formulate a literature review and exercise their professional voice within the LIS profession. His article embodies the role of the Editorial Advisory Board, which advises, mentors, and supports the work of the graduate student editors who perform the operations and editorial functions of the SRJ.

\section{Download and Publishing Characteristics}

A total of 66 papers have been published since the founding of the journal in 2010 across seven volumes, with two issues published in each volume. The average issue is comprised of one editorial, one invited faculty contribution, and three graduate student articles, offering the scholarly field of library and information science an average of six original articles per year. The largest volume, Volume 2, Issue 2 published in 2013, offers one editorial contribution, one invited faculty contribution and five student articles. Only one issue, Volume 6, Issue 2, includes a book review contribution by a student.

The $S R J$ has demonstrated a scholarly impact around the world on the field of library and information science (LIS). Since its inception, the journal has been downloaded in 189 different countries. Figure 1 represents the global reach of the $S R J$ by the number of full-text article downloads. 
Figure 1. Global Reach of the SRJ Journal by Article Download

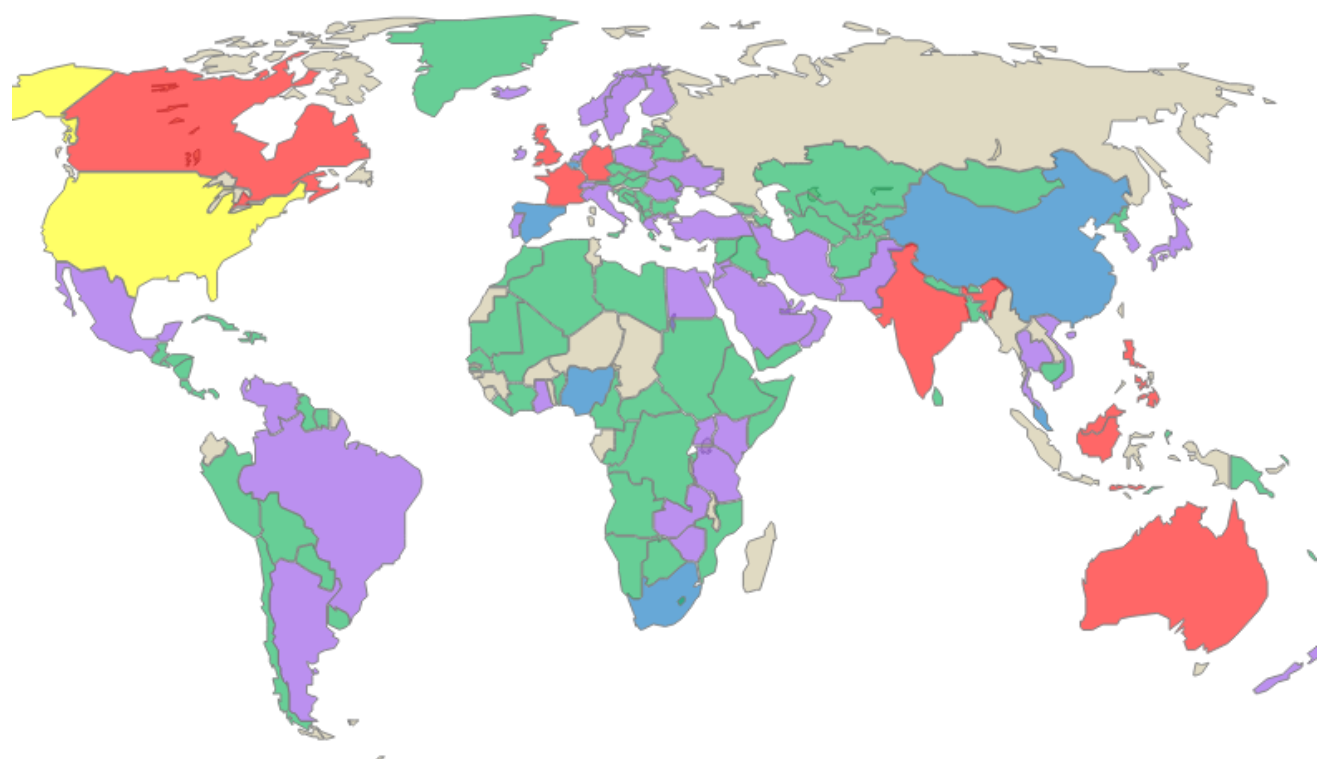

\begin{tabular}{|c|c|}
\hline \multicolumn{2}{|c|}{ School of Information Student Research Journal Downloads by Country } \\
\hline $36,000+$ Downloads & United States \\
\hline 1000-5000 Downloads & $\begin{array}{l}\text { Philippines, India, United Kingdom, Canada, Malaysia, France, Australia, } \\
\text { Germany, Indonesia }\end{array}$ \\
\hline 500-999 Downloads & $\begin{array}{l}\text { China, Nigeria, Singapore, Russian Federation, Spain, Netherlands, South } \\
\text { Africa }\end{array}$ \\
\hline 100-499 Downloads & $\begin{array}{l}\text { Kenya, Pakistan, Sweden, Brazil, Hong Kong, Vietnam, Ireland, Thailand, } \\
\text { South Korea, Japan, Iran, Mexico, Turkey, Italy, Egypt, Poland, New Zealand, } \\
\text { Zambia, Uganda, Saudi Arabia, Ukraine, Zimbabwe, United Arab Emirates, } \\
\text { Tanzania, Ghana, Portugal, Argentina, Taiwan, Israel, Columbia, Greece, } \\
\text { Romania, Switzerland, Denmark, Iraq. Belgium, Iceland, Lebanon, Slovakia, } \\
\text { Austria, Norway, Qatar, Oman }\end{array}$ \\
\hline 1-99 Downloads & $\begin{array}{l}\text { Sri Lanka, Ethiopia, Morocco, Jamaica, Algeria, Czech Republic, Estonia, } \\
\text { Croatia, Trinidad and Tobago, Bangladesh, Chile, Hungary, Slovenia, } \\
\text { Lithuania, Peru, Namibia, Kazakhstan, Serbia, Mauritius, Puerto rico, Bhutan, } \\
\text { Malta, Ecuador, Bulgaria, Kuwait, Nepal, Tunisia, Costa Rica, Botswana, } \\
\text { Jordan, Latvia, Malawi, Moldova, Brunei Darussalam, Cameroon, Venezuela, } \\
\text { Kyrgyzstan, Swaziland, Libya, Uzbekistan, Cambodia, Luxembourg, Sudan, } \\
\text { Albania, Macaa, Fiji, Barbados, Bahrain, Maldives, Seychelles, Cyprus, } \\
\text { Rwanda, Syrian Arab Republic, Belarus., Azerbaijan, El Salvador, Myanmar, } \\
\text { Senegal, Uruguay, Antigua, Barbuda, Dominican Republic, Guyana, } \\
\text { Nicaragua, Bolivia, Saint Lucia, Sierra Leone, Macedonia, Bahamas, Panama, } \\
\text { Georgia, Guatemala, Bosnia, Herzegovina, Cuba, Mongolia, Virgin Islands, } \\
\text { Yemen, Papua New Guinea, Armenia, Guam, Somalia, Afghanistan, Belize, } \\
\text { Curacao, Cayman Islands, Saint Vincent, Somoa, Faroe Islands, Grenada, } \\
\text { Lesotho Liberia, Honduras, Mozambique Benin, Isle of Men, Bermuda, } \\
\text { Democratic Republic of Congo, Dominica, Aruba, Korea, Liechtenstein, } \\
\text { Paraguay, Suriname, South Sudan, Guernsey, Angola, American Somoa, } \\
\text { Turkmenistan, Republic of Congo, Cook Islands, Cabo Verde, Djibouti, Enitrea, } \\
\text { Gibraltar, Greenland, Haiti, Jersey, Saint Kitts, Nevis, Lao People's } \\
\text { Democratic Republic, Montenegro, Mali, Northern Marian Islands, Martinique, } \\
\text { New Caledonia, French Polynesia, Solomon Islands, Tokelau, Burkina Faso, }\end{array}$ \\
\hline
\end{tabular}

While the United States represents the highest number of article downloads (36,972 downloads), the next nine countries representing the highest number of downloads, shown in red in Figure 1, span across the globe and include the Philippines (3692), India (3662), United Kingdom (2339), Canada (2037), Malaysia (1591), France (1510), Australia (1342), Germany (1137), and Indonesia (1126). Figure 1 demonstrates how a student-run scholarly journal is providing a viable avenue for students to contribute directly on key issues, trends, and issues impacting the LIS field that are of interest and value to the broader international community. 
The journal's most popular article, "Digital vs. Print: Reading Comprehension and the Future of the Book"

(http://scholarworks.sjsu.edu/slissrj/vol4/iss2/6) has been downloaded over 25,000 times (Tanner, 2014). In this article, iSchool student M. Julie Tanner explored the suitability of print, e-reader, and computer display reading platform for reading comprehension. The article demonstrated that "while printed books are most conducive to learning from longer, more difficult texts, e-readers and computer displays offer convenience and some distinct advantages to readers in particular situations" (Tanner, 2014, Abstract). The article, published in 2014, Volume 4, Issue 2 of the SLIS Student Research Journal is by far the most popular article in the $S R J$. Figure 2 shows the top ten downloaded article titles across all seven volumes.

Figure 2. Top 10 Full Text SRJ Articles

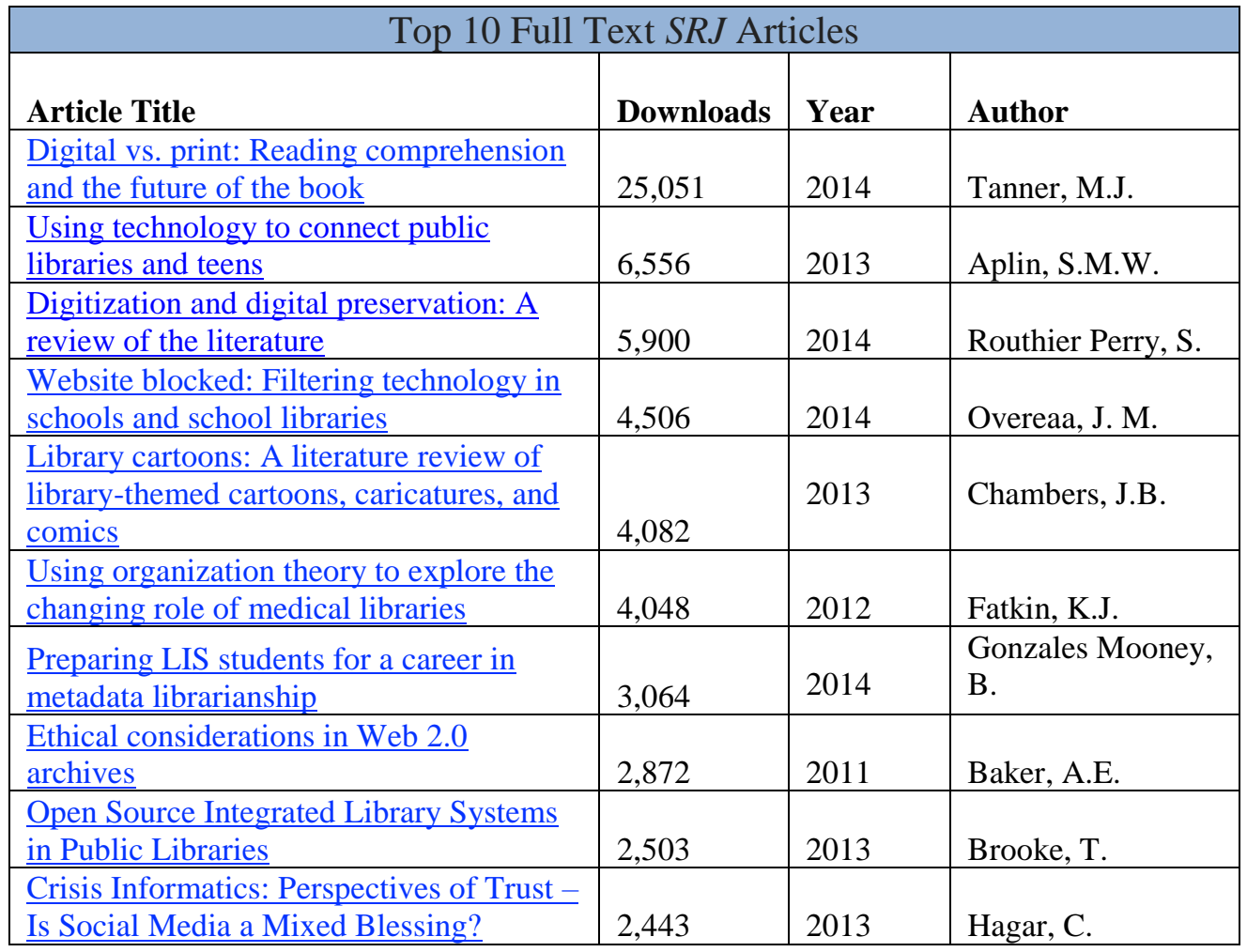

The topics addressed by these top ten most downloaded articles provide compelling evidence for how well the $S R J$ addresses a variety of trending research topics in the LIS field. In particular, these highly downloaded article topics frequently address the impact technology has in the LIS field and the way new and practicing professionals can embrace and innovate the role of technology, online materials, and social media within the LIS field. 


\section{SRJ's Contributor Characteristics}

The focus of the SRJ is on peer reviewed articles "submitted for consideration by graduate students from any institution in North America or internationally" (SRJ, 2018, About This Journal). By inviting graduate students from other MLIS programs to contribute, the opportunity for unique contributions from the field's newest professionals is expanded to include views, perspectives, and experiences that represent diverse types of scholarly communication and inquiry.

Stephens (2011), an iSchool Professor serving on the SRJ advisory board, emphasizes that many of these students bring in a wide range of backgrounds, prior career experiences, and differing cultural values that offer a mix of ideas, perspectives, and influences which will benefit the greater LIS community. He further states:

"These authors identify specific concerns among a breadth of issues and events that intersect our domains of knowledge. Explicit connections among these works may be relevant to not only the library information science community, but to all audiences. As we know of our online environment information can be ephemeral, presenting challenges to source and exchange credible, valued information." (Stephens, 2011, p.3)

An analysis of $S R J$ articles shows that 86 percent of the contributing authors are students at the SJSU School of Information. Fourteen percent of contributions (seven articles) come from students from other MLIS programs throughout the United States and beyond. Table 1 lists articles authored by non-SJSU students and their affiliations. As the table shows, three contributions are from SUNY Buffalo, one is from Syracuse University, one is from the University of Arizona, one is from University of Tennessee at Knoxville, and one is from the University of British Columbia in Canada.

Table 1. Non-SJSU Student Contributors

\begin{tabular}{|c|c|c|}
\hline Student Author & Article Title & $\begin{array}{l}\text { Non-SJSU MLIS } \\
\text { Program }\end{array}$ \\
\hline $\begin{array}{l}\text { Lindsay L. Marlow and } \\
\text { Amy Miller }\end{array}$ & $\begin{array}{l}\text { A picture is worth a thousand } \\
\text { words: The perplexing problem of } \\
\text { indexing images }\end{array}$ & $\begin{array}{l}\text { State University of New } \\
\text { York (SUNY) at Buffalo }\end{array}$ \\
\hline $\begin{array}{l}\text { Annalise Ammer and } \\
\text { Katherine Bertel }\end{array}$ & $\begin{array}{l}\text { \#Socialtagging: Defining its Role } \\
\text { in the Academic Library }\end{array}$ & SUNY Buffalo \\
\hline Amanda McCormick & $\begin{array}{l}\text { Copyright, Fair Use and the Digital } \\
\text { Age in Academic Libraries: A } \\
\text { Review of the Literature }\end{array}$ & SUNY Buffalo \\
\hline Mary Grace Flaherty & $\begin{array}{l}\text { Health Literacy: An overview of an } \\
\text { emerging field }\end{array}$ & Syracuse University \\
\hline Michel Castagné & $\begin{array}{l}\text { Consider the Source: The Value of } \\
\text { Source Code to Digital } \\
\text { Preservation Strategies }\end{array}$ & $\begin{array}{l}\text { The University of British } \\
\text { Columbia }\end{array}$ \\
\hline Camila Z. Tessler & $\begin{array}{l}\text { Privacy, Restriction, and Access: } \\
\text { Legal and Ethical Dilemmas } \\
\end{array}$ & University of Arizona \\
\hline Meredith K. Boehm & $\begin{array}{l}\text { An Exploratory Study of Online } \\
\text { Information Regarding Colony } \\
\text { Collapse Disorder }\end{array}$ & $\begin{array}{l}\text { University of Tennessee - } \\
\text { Knoxville }\end{array}$ \\
\hline
\end{tabular}




\begin{tabular}{|l|l|l|}
\hline Patricia Mars & Gender Demographics and & Catholic University \\
\hline
\end{tabular}

In addition to peer reviewed articles, each volume also includes at least one guest faculty or professional contribution, most who are iSchool faculty members who also serve on the SRJ Editorial Advisory Board. Holley Cornetto, the 2017-2018 editor of the $S R J$, states that "as a student-run journal, it is important to demonstrate that faculty support what we do" (Cornetto, 2018). Cornetto also emphasizes that welcoming instructor contributions offers the opportunity to introduce articles of interest to the iSchool audience and to introduce new and emerging topics that may be addressed in future curricula. Furthermore, inviting instructor contributions extends the learning experience beyond the classroom, providing an opportunity for both students and instructors to engage in a constant stream of conversation that "enables an understanding of participation that cannot be imparted within a closed environment" (Stephens, 2011, p.5). To date, there have been twelve total invited contributions, 10 of them who are iSchool faculty, one is a retired New Mexico librarian (Wiggins, 2014), and one faculty contribution from the University of Georgia (Swygart-Hobaugh, 2017).

\section{A Content Analysis of Article Topics and Trends Across the $S R J$}

The aims and scope of the $S R J$, as determined by the editorial team, focus on topics in library and information science, archives, policy, application, or practice which advance intellectual inquiry in the field (SRJ, 2018, Aims \& Scope). Students have the freedom to pick their topics within this scope and may perform original work based on professional interests, expand or redirect research or literature reviews done through coursework, or collaborate with other students on a unique topic or area of study.

Through a topic analysis of SRJ articles by MLIS graduate students and invited contributions from SJSU faculty and other professionals in the field, key topic trends and themes emerged. Table 2 outlines 11 topic trends, indicates the number of related articles in the journal, provides an exemplar article, and highlights the most downloaded article title within that topic.

Table 2. Student Research Journal: Key Topics and Trends

\begin{tabular}{|l|l|l|l|}
\hline Topic & $\begin{array}{l}\text { Number of } \\
\text { Contributions }\end{array}$ & Exemplar Article & $\begin{array}{l}\text { Most Downloaded } \\
\text { Article by Topic }\end{array}$ \\
\hline $\begin{array}{l}\text { All things digital: digital } \\
\text { literacy, digital } \\
\text { collections, and } \\
\text { digitization of film }\end{array}$ & $\bullet \begin{array}{l}4 \text { SJSU } \\
\text { student }\end{array}$ & $\begin{array}{l}\frac{\text { Information literacy in }}{\text { the digital age: Myths }} \\
\text { and principles of } \\
\frac{\text { digital literacy }}{\text { B.W. Becker }} \\
\text { SJSU graduate student } \\
\text { 1270 downloads }\end{array}$ & $\begin{array}{l}\frac{\begin{array}{l}\text { Digitization and digital } \\
\text { preservation: A review } \\
\text { of the literature }\end{array}}{\text { Perry S. Routhier }} \\
\text { SJSU graduate student } \\
5900 \text { downloads }\end{array}$ \\
\hline
\end{tabular}




\begin{tabular}{|c|c|c|c|}
\hline $\begin{array}{l}\text { Information seeking } \\
\text { behavior and how } \\
\text { patrons interact with } \\
\text { information differently } \\
\text { with information due to } \\
\text { increasing use of } \\
\text { technology. }\end{array}$ & $\begin{array}{ll} & 2 \text { SJSU } \\
\text { student } \\
1 \text { SUNY } \\
\text { Buffalo } \\
\text { student } \\
2 \text { SJSU } \\
\text { faculty }\end{array}$ & $\begin{array}{l}\text { Crisis informatics: } \\
\text { Perspectives of trust }- \\
\text { is social media a } \\
\text { mixed blessing? } \\
\text { C. Hagar } \\
\text { SJSU Faculty } \\
2443 \text { downloads }\end{array}$ & $\begin{array}{l}\text { Using technology to } \\
\text { connect public libraries } \\
\text { and teens } \\
\text { S.M.W. Aplin } \\
\text { SJSU graduate student } \\
6556 \text { downloads }\end{array}$ \\
\hline $\begin{array}{l}\text { Teaching frameworks, } \\
\text { information and digital } \\
\text { literacy, and research } \\
\text { skills in academic } \\
\text { libraries. }\end{array}$ & $\begin{array}{ll}- & 3 \text { SJSU } \\
& \text { student } \\
1 & 1 \text { SJSU } \\
& \text { editorial } \\
1 & 1 \text { SUNY } \\
& \text { Buffalo } \\
& \text { student } \\
1 & 1 \text { SJSU } \\
\text { faculty }\end{array}$ & $\begin{array}{l}\text { Sharpening the search } \\
\text { saw: Lessons from } \\
\text { expert searchers. } \\
\text { V.M. Tucker } \\
\text { SJSU Faculty } \\
1221 \text { downloads }\end{array}$ & $\begin{array}{l}\text { Copyright, fair use and } \\
\text { the digital age in } \\
\text { academic libraries: A } \\
\text { review of the literature. } \\
\text { A.McCormick } \\
\text { SUNY Buffalo student } \\
1772 \text { downloads }\end{array}$ \\
\hline $\begin{array}{l}\text { Research methodology, } \\
\text { e-journals, and } \\
\text { acquisitions, open access } \\
\text { journals, and metadata } \\
\text { for academic libraries. }\end{array}$ & $\begin{array}{ll}- & 4 \text { SJSU } \\
& \text { student } \\
- & 3 \text { SJSU } \\
& \text { editorial }\end{array}$ & $\begin{array}{l}\text { E-Journals and the big } \\
\text { deal: A review of the } \\
\text { literature } \\
\text { C. Sjoberg } \\
\text { SJSU student } \\
\text { 958 downloads }\end{array}$ & $\begin{array}{l}\text { Discovery tools and } \\
\text { local metadata } \\
\text { requirements in } \\
\text { academic libraries. } \\
\text { M.S. Wood } \\
\text { SJSU student } \\
1121 \text { downloads }\end{array}$ \\
\hline $\begin{array}{l}\text { Transitioning LIS skills } \\
\text { into professions and } \\
\text { developing skills for the } \\
\text { future. }\end{array}$ & $\begin{array}{ll} & 4 \text { SJSU } \\
& \text { student } \\
-\quad & 4 \text { SJSU } \\
& \text { faculty }\end{array}$ & $\begin{array}{l}\text { Beyond the walled } \\
\text { garden: LIS students } \\
\text { in an era of } \\
\text { participatory culture } \\
\text { M. Stephens } \\
\text { SJSU faculty } \\
\text { 1082 downloads }\end{array}$ & $\begin{array}{l}\frac{\text { Value of research }}{\text { methods courses: }} \\
\text { Voices from LIS } \\
\text { practitioners. } \\
\text { Lily Luo } \\
\text { SJSU faculty } \\
2108 \text { downloads }\end{array}$ \\
\hline $\begin{array}{l}\text { The rising need for } \\
\text { international } \\
\text { librarianship and } \\
\text { drawing attention to } \\
\text { gender issues and skills } \\
\text { of technology and } \\
\text { leadership to overcome } \\
\text { these inequalities in the } \\
\text { field. }\end{array}$ & $\begin{array}{ll}1 \text { SJSU } \\
\text { students } \\
\text { Catholic } \\
\text { University } \\
\text { of } \\
\text { America } \\
\text { student } \\
1 \text { SJSU } \\
\text { faculty }\end{array}$ & $\begin{array}{l}\text { Gender Demographics } \\
\text { and Perceptions in } \\
\text { Librarianship } \\
\text { P. Mars } \\
\text { Catholic University of } \\
\text { America student } \\
279 \text { downloads }\end{array}$ & $\begin{array}{l}\text { Strategies for engaging } \\
\text { in international } \\
\text { librarianship: } \\
\text { Misconceptions and } \\
\text { opportunities. } \\
\text { M. Sellar } \\
\text { SJSU Faculty } \\
\text { 510 downloads }\end{array}$ \\
\hline $\begin{array}{l}\text { The history of } \\
\text { librarianship and the } \\
\text { evolving profession. }\end{array}$ & $\begin{array}{ll} & 5 \text { SJSU } \\
& \text { student } \\
& 1 \text { SJSU } \\
& \text { editorial } \\
& 1 \text { SJSU } \\
\text { faculty }\end{array}$ & $\begin{array}{l}\text { The female librarian in } \\
\text { film: Has the image } \\
\text { changed in } 60 \text { years? } \\
\text { J.A. Wells } \\
\text { SJSU student } \\
1765 \text { downloads }\end{array}$ & $\begin{array}{l}\text { Library cartoons: A } \\
\underline{\text { literature review of }} \\
\underline{\text { library-themed cartoons, }} \\
\text { caricatures, and comics } \\
\text { J.B. Chambers } \\
\text { SJSU student } \\
\text { 4082 downloads }\end{array}$ \\
\hline
\end{tabular}




\begin{tabular}{|c|c|c|c|}
\hline $\begin{array}{l}\text { Importance of } \\
\text { collaborative scholarship } \\
\text { for LIS professionals } \\
\text { across all disciplines and } \\
\text { library environments, } \\
\text { including special } \\
\text { libraries. }\end{array}$ & $\begin{array}{ll}- & 1 \text { SJSU } \\
\text { student } \\
1 \\
\text { University } \\
\text { of } \\
\text { Tennessee } \\
- \\
\text { Knoxville } \\
\text { student } \\
2 \text { SJSU } \\
\text { editorial } \\
1 \text { SJSU } \\
\text { faculty }\end{array}$ & $\begin{array}{l}\frac{\text { Collaboration as an }}{\text { essential tool in }} \\
\text { information literacy } \\
\text { education 9-16: } \\
\text { Context, qualities and } \\
\text { implications } \\
\text { S. Godbey } \\
\text { SJSU editorial } \\
561 \text { downloads }\end{array}$ & $\begin{array}{l}\text { An exploratory study of } \\
\text { online information } \\
\text { regarding Colony } \\
\text { Collapse Disorder } \\
\text { M.K. Boehm } \\
\text { University of Tennessee } \\
\text { - Knoxville student } \\
729 \text { downloads }\end{array}$ \\
\hline $\begin{array}{l}\text { Issues in modern } \\
\text { collections development: } \\
\text { balancing digital and } \\
\text { print resources, } \\
\text { addressing questions of } \\
\text { diversity and access } \\
\text { of materials, and } \\
\text { selecting collections that } \\
\text { reflect current patron } \\
\text { needs. }\end{array}$ & $\begin{array}{ll} & 6 \text { SJSU } \\
\text { student } \\
1 \\
\text { University } \\
\text { of } \\
\text { Arizona } \\
\text { student }\end{array}$ & $\begin{array}{l}\text { Privacy, restriction, } \\
\text { and access: Legal and } \\
\text { ethical dilemmas. } \\
\text { C. Z. Tessler } \\
\text { University of Arizona } \\
374 \text { downloads }\end{array}$ & $\begin{array}{l}\text { Digital vs. print: } \\
\text { Reading comprehension } \\
\text { and the future of the } \\
\text { book } \\
25051 \text { downloads }\end{array}$ \\
\hline $\begin{array}{l}\text { Special libraries and } \\
\text { information } \\
\text { communities, including } \\
\text { isolated communities } \\
\text { such as inmates, the } \\
\text { homeless, and online } \\
\text { communities. }\end{array}$ & $\begin{array}{ll}\text { - } & \text { 6 SJSU } \\
\text { students } \\
1 \\
\text { Syracuse } \\
\text { student } \\
1 \text { Emporia } \\
\text { State } \\
\text { student } \\
1 \text { New } \\
\text { Mexico } \\
\text { Correction } \\
\text { al faculty }\end{array}$ & $\begin{array}{l}\text { Patient access to } \\
\text { electronic health } \\
\text { records: Strengths, } \\
\text { weaknesses and } \\
\text { what's needed to move } \\
\text { forward. } \\
\text { A. Zuniga } \\
\text { SJSU student } \\
1594 \text { downloads }\end{array}$ & $\begin{array}{l}\begin{array}{l}\text { Using organization } \\
\text { theory to explore the }\end{array} \\
\text { changing role of medical } \\
\text { libraries } \\
\text { K. J. Fatkin } \\
\text { Emporia State University } \\
\text { student } \\
4048 \text { downloads }\end{array}$ \\
\hline $\begin{array}{l}\text { The significance of well- } \\
\text { designed metadata with } \\
\text { modern databases, and } \\
\text { an increasingly digital } \\
\text { search and archival } \\
\text { process. }\end{array}$ & $\begin{array}{ll}- & 2 \text { SJSU } \\
& \text { students } \\
1 \text { State } \\
\text { University } \\
\text { of New } \\
\text { York at } \\
\text { Buffalo } \\
\text { student } \\
1 \\
\text { University } \\
\text { of British } \\
\text { Columbia } \\
\text { student }\end{array}$ & $\begin{array}{l}\text { Merging special } \\
\text { collections with GIS } \\
\text { technology to enhance } \\
\text { the user experience } \\
\text { G.L. Nichols } \\
\text { SJSU student } \\
288 \text { downloads }\end{array}$ & $\begin{array}{l}\text { Preparing LIS students } \\
\text { for a career in metadata } \\
\text { librarianship } \\
\text { B.Gonzales Mooney } \\
\text { SJSU student } \\
\text { 3064 downloads }\end{array}$ \\
\hline
\end{tabular}

The trending topics outlined in Table 2 represent the distinctive voice of each author and demonstrate how students interpret key topics and issues impacting the field of library and information science (Scott, 2011). Bernier (2011) notes that that the SRJ plays a "meaningful role in documenting graduate 
student views about 'where the field is' and where they believe it needs to go" ( $\mathrm{p}$. 8). With the student view, the LIS field is able to examine key topics and emerging trends through a different lens - the lens of the new professional who brings varying experiences and perspectives into consideration. Faculty and editorial contributions are also represented across these trending topics presented. Faculty contributions offer professional expertise and help connect the scholarly record to the classroom experience, while editorial contributions aim to bring all the contributions into query and reflection. Collectively, the $S R J$ offers the LIS field a valuable scholarly resource for all LIS professionals to learn, reflect, consider, participate, share, and continue the conversation.

\section{Conclusion}

Achieving the milestone of 100,000 SRJ downloads is a testimony to both the outstanding review process undertaken by the $S R J$ editorial team and the importance of bringing a student voice into broader LIS communication. The SRJ, as the only North American double-blind peer-reviewed, open access journal promoting graduate student scholarship in the LIS field, is an extremely valuable contribution to the future of the LIS profession and the future of LIS research. Since its initial publication in 2010, the $S R J$ has also demonstrated a breadth of scholarship that has strong relevancy to trending LIS themes. As the review of literature on the topic of LIS scholarship and MLIS student research coursework and ethos indicates, there is a lack of engagement and contribution to scholarly communication and research. The $S R J$ overcomes this barrier to research and publication through its devotion to encouraging graduate student participation and bringing global, open access visibility to the significance of MLIS student research and future LIS scholarly inquiry. The $S R J$ provides students a unique opportunity to chart "a new direction for the scholarship in our field: articulating a direction in which the field should take the next "turn." (Bernier, p.

$8)$. The $S R J$ is a powerful example of how educational institutions support students in becoming engaged LIS practitioners and research pioneers.

\section{References}

Aplin, S. M. W. (2013). Using technology to connect public libraries and teens. SLIS Student Research Journal, 2(2). Retrieved from http://scholarworks.sjsu.edu/cgi/viewcontent.cgi $?$ article $=1098 \&$ context $=$ slis $S$ $\underline{\mathrm{RJ}}$

Ammer, A., \& Bertel, K. (2011). \#Socialtagging: Defining its role in the academic library. SLIS Student Research Journal, 1(2). Retrieved from http://scholarworks.sjsu.edu/cgi/viewcontent.cgi $?$ article $=1058 \&$ context $=$ slis $S$ $\underline{\mathrm{RJ}}$

Becker, B. W. (2018). Information literacy in the digital age: Myths and principles of digital literacy. School of Information Student Research Journal, 7(2). Retrieved from 
http://scholarworks.sjsu.edu/cgi/viewcontent.cgi?article=1316\&context=slisS $\underline{\mathrm{RJ}}$

Bernier, A. (2011). Reaching escape velocity and the purpose of SLIS Student Research Journal. SLIS Student Research Journal, 1(1). Retrieved from http://scholarworks.sjsu.edu/cgi/viewcontent.cgi?article $=1032 \&$ context=slisS $\underline{\mathrm{RJ}}$

Boehm, M. K. (2012). An exploratory study of online information regarding Colony Collapse Disorder. SLIS Student Research Journal, 2(1). Retrieved from http://scholarworks.sjsu.edu/cgi/viewcontent.cgi?article $=1055 \&$ context=slisS $\underline{\mathrm{RJ}}$

Castagné, M. (2013). Consider the Source: The Value of Source Code to Digital Preservation Strategies. SLIS Student Research Journal, 2(2). Retrieved from http://scholarworks.sjsu.edu/cgi/viewcontent.cgi?article=1069\&context=slisS $\underline{\mathrm{RJ}}$

Chambers, J. B. (2013). Library cartoons: A literature review of library-themed cartoons, caricatures, and comics. SLIS Student Research Journal, 3(1). Retrieved from http://scholarworks.sjsu.edu/cgi/viewcontent.cgi?article=1072\&context=slisS $\underline{\mathrm{RJ}}$

Cornetto, H. (2018). Email dated April 19, 2018.

Cornetto, H. (2018). Stepping into the future. School of Information Student Research Journal, 7(2). Retrieved from http://scholarworks.sjsu.edu/cgi/viewcontent.cgi?article=1034\&context=slisS $\underline{\mathrm{RJ}}$

Evans, A., Dresang, E., Campana, K., and Feldman, E. (2013). Research in action: Taking classroom learning to the field. Journal of Education for Library \& Information Science. 54(3). p. 244-252.

Flaherty, M. G. (2011). Health literacy: An overview of an emerging field. SLIS Student Research Journal, 1(2). Retrieved from http://scholarworks.sjsu.edu/cgi/viewcontent.cgi?article=1034\&context=slisS $\underline{\mathrm{RJ}}$

Hagar, C. (2013). Crisis informatics: Perspectives of trust - is social media a mixed blessing? SLIS Student Research Journal, 2(2). Retrieved from http://scholarworks.sjsu.edu/cgi/viewcontent.cgi?article $=1121 \&$ context=slis $S$ $\underline{\mathrm{RJ}}$

Hayman, R. (2015). [Review]. LIS Periodicals contain a low percentage of articles that qualify as research. Evidence Based Library \& Information Practice, 10(4). p. 218-220.

Hirsh, S., Faires, D., Holschuh Simmons, M., Christensen, P., Sellar, M., Stenström, C., Hagar, C., Bernier, A., Alman, S., \& Fisher, J. (2015). International Perspectives in LIS Education: Global Education, Research, \& Collaboration at the SJSU School of Information. Journal of Education for Library and Information Science, 56(Supplement 1). p. S27-S46.

Hockin, T. (2017). Structure and significance. SLIS Student Research Journal, 7(1). Retrieved from 
http://scholarworks.sjsu.edu/cgi/viewcontent.cgi?article=1297\&context=slisS $\underline{\mathrm{RJ}}$

Lankes, R. D. (2011). The Atlas of New Librarianship. Cambridge, Ma: MIT Press.

Lou, L. (2012). Value of research methods courses: Voices from LIS practitioners. SLIS Student Research Journal, 2(1). Retrieved from $\underline{\text { http://scholarworks.sjsu.edu/cgi/viewcontent.cgi? article=1091\&context=slisS }}$ $\underline{\mathrm{RJ}}$

Lowdermilk, L. (2018). Publication spotlight: School of Information Student Research Journal. LIS Publication Wiki. Retrieved from http://ischoolwikis.sjsu.edu/lispublications/publication-spotlight-school-ofinformation-student-research-journal/

Marlow, L. L., \& Miller, A. (2011). A picture is worth a thousand words: The perplexing problem of indexing images. SLIS Student Research Journal, 1(2). Retrieved from http://scholarworks.sjsu.edu/cgi/viewcontent.cgi?article=1296\&context=slisS $\underline{\mathrm{RJ}}$

Mars, P. (2018). Gender Demographics and Perceptions in Librarianship. School of Information Student Research Journal, 7(2). Retrieved from http://scholarworks.sjsu.edu/cgi/viewcontent.cgi?article=1296\&context=slis $S$ $\underline{\mathrm{RJ}}$

McCormick, A. (2014). "Copyright, fair use and the digital age in academic libraries: A review of the literature. SLIS Student Research Journal, 4(2). Retrieved from $\underline{\text { http://scholarworks.sjsu.edu/cgi/viewcontent.cgi? article=1171\&context=slisS }}$ $\underline{\mathrm{RJ}}$

Otero-Boisvert, M. (2011). Participating in the conversation." SLIS Student Research Journal, 1(2). Retrieved from http://scholarworks.sjsu.edu/cgi/viewcontent.cgi?article $=1068 \&$ context=slis $S$ $\underline{\mathrm{RJ}}$

Partridge, H.H., and Given. L.I. (2016) Research is vital. Incite. 37(9/10).

Perilli, N. (2017). Research-savvy iSchool alumna graduates with a career waiting for her. Community Profiles. SJSU School of Information. Retrieved from https://ischool.sjsu.edu/people/community-profile/tamarack-hockin

Routhier Perry, S. (2014). Digitization and digital preservation: A review of the literature. SLIS Student Research Journal. 4(1). Retrieved from $\underline{\text { http://scholarworks.sjsu.edu/cgi/viewcontent.cgi?article=1170\&context=slisS }}$ $\underline{\mathrm{RJ}}$

Scott, S. (2011). Collaborative scholarship in library and information science. SLIS Student Research Journal, 1(1). Retrieved from http://scholarworks.sjsu.edu/cgi/viewcontent.cgi?article $=1033 \&$ context=slis $S$ $\underline{\mathrm{RJ}}$

Sellar, M. (2016). Strategies for engaging in international librarianship: Misconceptions and opportunities. SLIS Student Research Journal, 6(1). Retrieved from 
http://scholarworks.sjsu.edu/cgi/viewcontent.cgi?article=1251\&context=slisS $\underline{\mathrm{RJ}}$

Sjoberg, C. (2017). E-Journals and the big deal: A review of the literature. SLIS Student Research Journal, 6(2). Retrieved from http://scholarworks.sjsu.edu/cgi/viewcontent.cgi?article $=1252 \&$ context=slisS $\underline{\mathrm{RJ}}$

Stephens, M. (2011). Beyond the walled garden: LIS students in an era of participatory culture. SLIS Student Research Journal, 1(2). Retrieved from http://scholarworks.sjsu.edu/cgi/viewcontent.cgi?article $=1067 \&$ context=slisS $\underline{\mathrm{RJ}}$

Student Research Journal. (2018). About this Journal. Retrieved from http://scholarworks.sjsu.edu/slisSRJ/about.html

Students Research Journal. (2018). Aims \& Scope. http://scholarworks.sjsu.edu/slisSRJ/aimsandscope.html

Student Research Journal. (2018). SRJ Editorial Structure Chart. https://drive.google.com/open?id=0B3MpMolmsWhvQXo1OFRBQUZwZEU

Student Research Journal. (2018). Name Change. Retrieved from http://scholarworks.sjsu.edu/slisSRJ/

Swygart-Hobaugh, A. J. (2017). Data services in academic libraries - What strange beast is this? SLIS Student Research Journal, 6(2). Retrieved from http://scholarworks.sjsu.edu/slisSRJ/vol6/iss $2 / 2$

Tanner, M. J. (2014). Digital vs. print: Reading comprehension and the future of the book. SLIS Student Research Journal, 4(2). Retrieved from http://scholarworks.sjsu.edu/slisSRJ/vol4/iss2/6

Tessler, C. Z. (2014). Privacy, restriction, and access: Legal and ethical dilemmas. SLIS Student Research Journal, 4(1). Retrieved from http://scholarworks.sjsu.edu/cgi/viewcontent.cgi?article=1164\&context=slisS $\underline{\mathrm{RJ}}$

Tucker, V. M. (2015). Sharpening the search saw: Lessons from expert searchers. SLIS Student Research Journal, 5(1). Retrieved from http://scholarworks.sjsu.edu/cgi/viewcontent.cgi?article=1214\&context=slis $S$ $\underline{\mathrm{RJ}}$

Turcios, M.E., Agarwal, N.K., and Watkins, L. (2014). How much of library and information science literature qualifies as research? Journal of Academic Librarianship. 40 (5). p. 473-479. Retrieved from https://doi.org/10.1016/j.acalib.2014.06.003

Wells, J. A. (2013). The female librarian in film: Has the image changed in 60 years? SLIS Student Research Journal, 3(2). Retrieved from http://scholarworks.sjsu.edu/cgi/viewcontent.cgi?article=1125\&context=slisS $\underline{\mathrm{RJ}}$

Wiggins, V. (2014). A correctional type of day. SLIS Student Research Journal, 4(2). Retrieved from http://scholarworks.sjsu.edu/slisSRJ/vol4/iss $2 / 2$

Wood, M. S. (2011). Discovery tools and local metadata requirements in academic libraries. SLIS Student Research Journal, 1(1). Retrieved from http://scholarworks.sjsu.edu/cgi/viewcontent.cgi?article $=1018 \&$ context=slis $S$ $\underline{\mathrm{RJ}}$ 
School of Information Student Research Journal, Vol. 8, Iss. 1 [2018], Art. 3

https://scholarworks.sjsu.edu/ischoolsrj/vol8/iss1/3

DOI: 10.31979/2575-2499.080103 